\title{
Pelaksanaan Bagi Hasil Simpanan dan Pembiayaan Mudharabah di BMT Al-Amanah \\ Cabang Subang

\author{
Rina Lestari ${ }^{1}$, Ahmad Damiri ${ }^{2}$, Jalaludin ${ }^{3}$ \\ ${ }^{1}$ STAI Riyadhul Jannah \\ ${ }^{2,3}$ STIES Indonesia Purwakarta
}

Jln. Veteran no 150-152 Purwakarta 41118 Jawa Barat INDONESIA

\author{
${ }^{1}$ letaririna@gmail.com \\ 2ahmad.damiri86@gmail.com \\ 3 jalaludin@sties-purwakarta.ac.id
}

\begin{abstract}
Abstrak_Artikel ini membahas tentang pelaksanaan bagi hasil simpanan dan pembiayaan dengan menggunakan akad Mudharabah di BMT Al-Amanah Cabang Subang. Tujuan dari penelitian ini adalah untuk mengetahui ketentuan bagi hasil Mudharabah menurut para ulama, mengetahui pelaksanaan bagi hasil simpanan dan pembiayaan Mudharabah, dan untuk mengetahui dampak dari bagi hasil simpanan dan pembiayaan Mudharabah. Metode penelitian yang digunakan adalah kualitatif dengan pendekatan empiris. Teknik pengumpulan data yang digunakan adalah observasi, wawancara, dan dokumentasi. Dalam penelitian ini sumber data terdiri dari data primer dan data sekunder. Data Primer diperoleh dari hasil lapanganan data sekunder terdiri dari referensi, buku-buku, dan sumber dari internet. Hasil Penelitian menunjukan bahwa simpanan dan pembiayaan Mudharabah yang dilakukan di BMT AlAmanah yaitu menggunkan Mudharabah mutlaqah dan nisbah bagi hasil yang dipakai adalah revanue sharing, menurut para ulama akad Mudharabah boleh dilakukan dengan syarat atau ketentuan yang sudah disepakati. Di BMT Al-Amanah ini nisbah bagi hasil hanya beda dalam penghitungan atau pembagian saja, pembagian nisbah 40:60 ada yang 50:50 tergantung dari kesepakatan yang dilakukan kedua belah pihak, selanjutnya manfaat atau dampak positif dapat membantu para anggota dalam melakukan penyimpanan dana maupun dalam pembiayaan dana, dan juga dapat membatu dan mengembangkan BMT Al-Amanah dalam mengelola dan membesarkan lembaga keuangan tersebut.
\end{abstract}

Kata kunci_Bagi Hasil, Mudharabah, Para Ulama, Mutlaqah,Revanue Sharing.

\begin{abstract}
This article discusses the implementation of profit sharing and financing using Mudharabah agreements at BMT Al-Amanah Subang Branch. The purpose of this study is to determine the Mudharabah profit sharing provisions according to the scholars, to know the implementation of Mudharabah savings and financing profit sharing, and to determine the impact of Mudharabah profit sharing and financing. The research method used is qualitative with an empirical approach. Data collection techniques used were observation, interviews, and documentation. In this study the data source consisted of primary data and secondary data. Primary data obtained from the field and secondary data consist of references, books, and sources from the internet. Research results show that Mudharabah savings and financing carried out at BMT Al-Amanah that is using mudlaabah mutlaqah and profit sharing ratio used is revanue sharing, according to ulama Mudharabah agreements may be carried out on agreed terms or conditions. In BMT Al-Amanah the profit sharing ratio differs only in calculation or distribution, there is a 50:60 ratio sharing 50:50 depending on the agreement made by both parties, then the benefits or positive impact can help members in saving funds or in funding funds, and can
\end{abstract}

Keywords_Profit Sharing, Mudharabah, Ulama, Mutlaqah, Revanue Sharing.

Rina Lestari | Pelaksanaan Bagi Hasil Simpanan ...... | 32 


\section{PENDAHULUAN}

Islam diturunkan kepada manusia untuk membawa pada kehidupan yang diwarnai dengan nilai-nilai kebaikan (maslahat) baik untuk diri sendiri maupun lingkungannya. Begitupun islam juga mendorong umatnya untuk mendapatkan harta dengan berbagai cara, asalkan mengikuti peraturan-peraturan yang telah ditetapkan dalam islam (Yuliadi, 2001).

Sejak awal kelahirannya perbankkan syariah memiliki tujuan dan berlandaskan etika dalam aspek kehidupan ekonomi yang berlandaskan alqur'an. Pada era saat ini, dunia pebankkan sangatlah dipercaya oleh masyarakat untuk memberikan jasa penyimpanan uang ataupun harta mereka, sehingga dapat memberikan keaman dan jaminan untuk harta tersebut (Handayani, 2013). Perkembangan perbankan syariah/lembaga keuangan yang saat ini sebagai salah satu upaya meningkatkan dan mengembangkan kesejahteraan ekonomi indonesia dari waktu ke waktu sangat menggembirakan. Untuk menjamin kesyariahan bank, undang-undang telah menegaskan bahwa setiap bank syariah harus dibentuk pasal 32 (1) dewan pengawas syariah (pasal 32 ayat 1).

Bank syariah pada saat ini lebih banyak diminati oleh kalangan masyaraka untuk menabung atau menginvestasikan harta mereka ke bank syariah (Malik, 2017; Mulato, 2019), hal ini mencerminkan semangat beragama dan marwah masyarakat dalam investasi syariah. Bersamaan dengan itu maka mulai banyak instrumentinstrument bermunculan atau insitusi yang mulai beroperasi secara islami. Sebagai contoh muncul lembaga-lembaga bank islam, asuransi islam dan sebagainya. Seperti BMT Al-Amanah Cabang Subang yang menerapkan pelaksanaan akad-akad yang dipakai dalam suatu pelaksanaan simpanan dan pembiayaan di koperasi tersebut.

Banyaknya koperasi-koperasi syariah yang bermunculan. Koperasi syariah adalah badan usaha koperasi yang menjalankan usahanya menggunakan prinsip, tujuan dan kegiatan usaha dengan konsep syariah (Sofiana, 2014). Koperasi syariah mulai gencar dibicarakan setelah adanya pertumbuhan pesat Baitul Mal wa Tamwil (BMT) di Indonesia yang kemunculannya hampir sama dengan BMI, yakni pada tahun 1992. Kemunculan BMT ini memberikan warna baru dalam perkembangan ekonomi syariah, terutama pada sektor mikro (Sumirto, 2002).

Peran BMT dalam menumbuh kembangkan usaha mikro dan usaha kecil dilingkungannya merupakan sumbangan yang sangat berarti bagi pembangunan ekonomi masyarakat. Bank yang diharapkan mampu menjadi perantara keuangan ternyata hanya mampu bermain dalam level menengah atas. Sedangkan lembaga keuangan non-Formal yang notabennya mampu menjangkau pengusaha mikro tidak mampu meningkatkan kapitalis usaha kecil (Mulato, 2019). Mudharabah berasal dari kata "dharb", berarti memukul atau berjalan. Pengertian memukul atau berjalan ini lebih tepatnya adalah proses seseorang memukulkan kakinya dalam menjalankan usaha (Antonio, 2001).

Adapun ketentuan-ketentuan yang harus dipenuhi antar kedua belah pihak untuk Pembiayaan Mudharabah. Adapun ketentuanketentuan tersebut adalah : Diutamakan kepada pedagang. Sasaran utama pada produk ini adalah membantu para pedagang kecil dalam mengakses dana. Sehingga dapat menjadi lebih baik kedepannya, usaha yang dijalani minimal sudah berjalan satu tahun agar dalam masa pembayaran tidak mengalami kemacetan dan dapat berjalan lancar dalam pembayaran, adanya bagi hasil, pembayaran angsuran berjalan lancar.

Sedangkan dalam Fatwa al-Muashirah disebutkan bahwa mudharabah dalam fiqh islam merupakan salah satu dari jenis syirkah yang didalamnya ada pokok modal ( $r a$ 's al'mal) dari satu pihak dan pekerjaan ('amal) dari pihak yang lain. Mekanismenya, seseorang menyerahkan harta kepada pihak lain untuk diniagakan dengan keuntungan yang diperoleh dibagi (Janwari, 2015).

Keuntungan usaha secara mudharabah, dibagi menurut kesepakatan yang dituangkan dalam kontrak. Apabila rugi, ditanggung oleh pemilik modal selama bukan akibat kelalaian si pengelola. Seandainya kerugian tersebut disebabkan oleh kelalaian atau kecurangan pengelola, si pengelola 


\section{EKSISBANK Vol. 4 No. 1 Juni 2020}

harus bertanggung jawab atas kerugian yang terjadi.

Adapun dasar hukum pelaksanaan akad Mudharabah adalah firman Allah SWT. Dalam Al-Qur'an Surat Al-Baqarah Ayat 283:

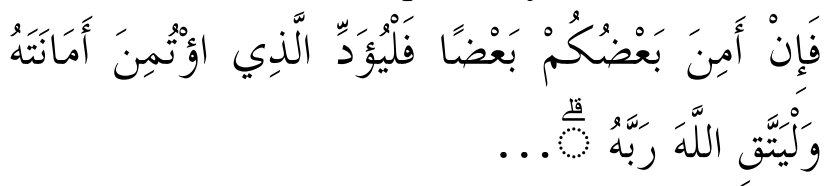

"... Maka, jika sebagian kamu mempercayai sebagian yang lain, hendaklah yang dipercayai itu menunaikan amanatnya dan hendaklah ia bertakwa kepada Allah Tuhannya ..."

Hadist Nabi riwayat Ibnu Majah dari Shuhaib: "Nabi bersabda, 'Ada tiga hal yang mengandung berkah: jual beli tidak secara tunai, muqaradhah (Mudharabah), dan mencampur gandum dengan jewawut untuk keperluan rumah tangga, bukan untuk dijual." (HR. Ibnu Majah dari Shuhaib).

Berdasarkan uraian diatas mengenai definisi dasar hukum dari akad tersebut, maka dapat dipahami bahwa akad Mudharabah adalah suatu akad perjanjian kerja antara dua pihak. Akad Mudharabah disebut sah apabila memenuhi syarat dan rukun yang sudah ditentukan. Secara definisi profit sharing diartikan:" Distribusi beberapa bagian dari laba para pegawai dari suatu perusahaan." Lanjut laba dikatakan, bahwa hal itu dapat berbentuk suatu bonus uang tunai tahunan yang didasarkan pada laba yang diperoleh pada tahun-tahun sebelumnya, atau dapat berbentuk pembayaran mingguan atau bulanan.

Beberapa penelitian tentang bagi hasil simpanan dan pembiayaan dengan menggunakan akad Mudharabah sudah banyak dilakukan oleh penelitian sebelumnya seperti yang dilakukan oleh Mega Juliana dengan judul "Pelaksanaan Akad Mudharabah pada Simpanan Di BMT Walisongo Semarang" dalam penyelesaiannya penulis menggunakan metode dalam pengumpulan data primer maupun sekunder yakni dengan wawancara, observasi dan dokumentasi. Dalam menganalisa data penulis menggunakan metode analisis deskriptif. Dengan hasil penelitian tersebut menyimpulkan bahwa pelaksanaan akad Mudharabah pada simpanan serbaguna pada BMT Walisongo Semarang menggunakan akad Mudharabah mutlaqah.
Nisbah keuntungan yang tidak memberatkan pengelola menjadi pengelola menjadi kunci sukses perjalanan BMT hingga sekarang.

Adapun tujuan dari penelitian ini adalah untuk mengetahui ketentuan bagi hasil. Mudharabah menurut para ulama, untuk mengetahui pelaksanaan bagi hasil simpanan dan pembiayaan Mudharabah di BMT Al-Amanah Cabang Subang, untuk mengetahui dampak dari bagi hasil simpanan dan pembiayaan Mudharabah di BMT Al-Amanah Cabang Subang. Dengan skripsi ini saya maupun masyarakat lebih mengerti tentang produk-produk yang menggunakan akad Mudharabah.

\section{METODOLOGI PENELITIAN}

Metode yang digunakan dalam penelitian ini adalah metode deskriptif kualitatif yaitu penelitian yang menggambarkan serta menyajikan suatu peristiwa yang terjadi di lapangan dengan menggunakan teknik pengumpulan trigulasi data yaitu melalui observasi, wawancara, dokumentasi, dan juga penelitian kepustakaan dengan membaca buku, jurnal. Artikel, website yang berkaitan dengan masalah yang akan diteliti (Bagoes, 2004).

Peneliti akan mencari tahu bagaiman sistem bagi hasil dengan menggunakan akad Mudharabah dalam produk simpanan dan pembiayaan yang ada di BMT Al-Amanah Cabang Subang. Dan dampak pelaksaan simpanan dan pembiayaan dengan menggunakan akad Mudharabah untuk BMT maupun untuk nasabah yang melakukan akad kerja sama tersebut. Penelitian deskriptif merupakan penelitian yang berusaha mendeskripsikan sesuatu.

Penelitian yang penulis gunakan menurut tiga studi yang dijelaskan Robert $\mathrm{K}$ Yin yaitu penelitian eksplanasi. Karena penelitian eksplanasi dimaksudkan agar peneliti lebih mengetahui dan mengembangkan konsep sesuai dengan keadaan lapangan. Penelitian ini tidak harus dilakuan oleh orang yang sudah mahir dalam masalah yang diteliti tersebut. Orang atau masyarakat sering tidak puas hanya sekedar mengetahui apa yang terjadi, bagaimana terjadinya, tetapi juga ingin tahu mengapa hal tersebut bisa terjadi. Oleh sebab itu penulis 


\section{EKSISBANK Vol. 4 No. 1 Juni 2020}

bertujuan untuk mengkonfirmasi sebab terjadinya suatu masalah.

Data primer merupakan data yang diperoleh secara langsung oleh penulis dari responden terpilih, pada lokasi penelitian. Data primer diperoleh dengan cara wawancara pada tanggal 15 mei 2019 penulis mendatangi pengelola dan anggota yang melakukan kerja sama dengan menggunakan akad Mudharabah di BMT AlAmanah Cabang Subang, berbagai pertanyaan yang penulis tanyakan seperti (Satya, 2019):

Produk apa saja di BMT Al-Amanah cabang subang yang menggunakan akad Mudharabah Apakah dari semua produk yang menggunakan akad Mudharabah menguntungkan bagi pihak BMT, keunggulan apa saja dari berbagai produk dengan yang menggunakan akad Mudharabah, Prosedur dan syarat apa saja yang diperlukan para nasabah untuk melakukan kerja sama produk yang menggunakan akad Mudharabah, Bagaimana proses bagi hasil yang dilakukan pihak BMT untuk produk Mudharabah tersebut, Manfaat apa saja yang didapat BMT dari yang melakukan kerja sama dengan menggunakan akad Mudharabah ini.

Adapun data sekunder merupakan data yang diperoleh dari jurnal, skripsi, situs internet, serta bacaan lain yang berhubungan dengan penelitian yang digunakan sebagai data penunjang (Ahmad et al., 2019). Adapun teknik pengumpulan data yaitu yang pertama observasi yaitu dengan melakukan pengamatan langsung terhadap objek dan peneliti, kemudian wawancara merupakan pertemuan dua orang untuk bertukar informasi melalui tanya jawab dengan mengajukan pertanyaan yaitu pengumpulan data yang dilakukan dengan cara memberikan daftar pertanyaan kepada ketua cabang dan nasabah BMT Al-amanah Cabang Subang.

Setelah mendapatkan data kemudian menggunakan keabsahan data dengan mencari tahu sesuatu hal yang lain diluar data yang ada untuk keperluan pengecekan atau sebagai pembanding. Dengan dilengkapi penelitian yang dilakukan dengan cara pengumpulan data, melalui bahan-bahan kepustakaan berupa tulisan-tulisan ilmiah, jurnal, laporan penelitian, buku-buku, dan sumber lain seperti internet yang berhubungan dengan topik yang diteliti.

Kemudian penulis melakukan upaya untuk mencari secara sistematis hasil observasi, wawancara untuk meningkatkan pemahaman penelitian tentang kasus yang diteliti. Agar dapat memecahkan dan menyelesaikan masalahmasalah yang sedang penulis teliti dalam menyelesaikan tugas akhir ini untuk mendapat gelar sarjana.

Islam diturunkan kepada manusia untuk membawa pada kehidupan yang diwarnai dengan nilai-nilai kebaikan (maslahat) baik untuk diri sendiri maupun lingkungannya. Begitupun islam juga mendorong umatnya untuk mendapatkan harta dengan berbagai cara, asalkan mengikuti peraturan-peraturan yang telah ditetapkan dalam islam (Yuliadi, 2001).

\section{HASIL DAN PEMBAHASAN}

Hasil penelitian hendaknya dituliskan secara jelas dan padat. Diskusi hendaknya menguraikan arti pentingnya hasil penelitian, bukan mengulanginya. Hindari penggunaan sitasi dan diskusi yang berlebihan tentang literatur yang telah dipublikasikan.

Hasil dari analisis data yang dilakukan di BMT Al-Amanah Cabang Subang, menurut para ulama boleh saja dilakukan asal sesuat syarat dan rukun yang sudah ditentukan dan ada beberapa produk yang menggunakan akad Mudharabah yang dikeluarkan oleh BMT Al-Amanah Cabang Subang.

Ibnu Mudzir berkata, "para ulama sepakat bahwa pekerja harus mensyaratkan kepada pemilik modal bahwa ia mendapatkan sepertiga atu setengah dari laba, atau berdasarkan kesepakatan keduanya setelah laba tersebut diketahui bagian-bagiannya. Seandainya ditetapkan untuk semua laba, sejumlah dirham yang telah diketahui sebelumnya atau bagian yang tidak diketahui, maka kongsi ini tidak sah (Hendri, 2013).

Menurut para fuqaha, Mudharabah adalah akad antara dua pihak (orang) saling menanggung, salah satu pihak menyerahkan hartanya kepada pihak lain untuk diperdagangkan dengan bagian yang telah ditentukan dari keuntungan, seperti 


\section{EKSISBANK Vol. 4 No. 1 Juni 2020}

setengah atau sepertiga dengan syarat-syarat yang telah ditentukan. Salah satunya yang dikemukakan oleh Hasby Ash Shiddieqy mengatakan bahwa Mudharabah dan bagi hasil adalah semacam syarikat akad, bermufakat dua orang padanya dengan kenteuan: modal dari satu pihak, sedangkan usaha menghasilkan keuntungan dari pihak yag lain, dan keuntungankeuntungan dibagi antara mereka (Yarmunida \& Wulandari, 2018) (Arianti, 2018).

Dari uraian diatas penulis menyimpulkan tentang bagi hasil Mudharabah menurut para ulama boleh dilakukan dan harus sesuai dengan aturan yang sudah disesuaikan didalam kententuan-ketentuan bagi hasil dengan menggunakan akad Mudharabah. Dengan catatan shahibul mall maupun mudharib harus mengerti dan memahami akad tersebut agar kerja sama yang dilakukan dapat berjalan lancar sesuai ketentuan yang sudah ditetapkan dan tidak terjadi kesalah pahaman.

DPS (Dewan Pengawas Syariah) pun membolehkan hal tersebut asal sesuai dengan ketentuannya. Sering kali nasabah salah mengartikan akad Mudharabah tersebut karena tidak paham dan tidak memahami terlebih dahulu akad tersebut.

Dari produk Simpanan ada dua produk yang menggunakan akad Mudharabah:

\section{Tabungan Mudharabah}

BMT Al-Amanah dalam penerapan bagi hasil akad Mudharabah mengunakan sistem bagi hasil Revanue Sharing yang perhitungannya didasarkan kepada hasil atau pendapatan. Dalam produk tabungan Mudharabah ini BMT menggunakan akad Mudharabah mutlaqah, yakni pihak pemodal menyerahkan seluruh modal berupa uangnya kepada pengelola; baik jenis usaha, waktu, dan tempat. Dengan nisbah atau bagi hasil tabungan Mudharabah sebesar 40\%:60\% persentase tersebut 40\% untuk nasabah dan $60 \%$ untuk pengelola.

Berikut contoh perhitungan nisbah atau bagi hasil untuk tabungan Mudharabah : Saldo rata-rata nasabah sebesar Rp. 2.100 .000 sedangkan bagi hasil yang dikumpulkan BMT Al-Amanah pada bulan Juli 2018 sebesar Rp. 4.000.000 dengan saldo rata-rata investasi tabungan di BMT Al-Amanah Cabang subang sebesar Rp. 50.000.000 dengan perhitungan bagi hasil 40:60 data tersebut diperoleh. Saldo rata-rata nasabah dibagi dengan saldo rata-rata investasi tabungan di BMT, setelah itu dikalikan dengan nisbah yang didapatkan pada bulan juli dan dibagikan sesuai dengan kesepakatan yaitu 40:60. Berikut perhitungannya :

Rp. $2.100 .000 /$ Rp. $50.000 .000=0,042$ 0,042 x Rp. 4.000 .000 x $40 \%=$ Rp. 67.200 Jadi nisbah bagi hasil yang didapatkan oleh oleh nasabah pada bulan juli 2018 adalah Rp. 67.200, bagi hasil tersebut bisa saja berubah setiap bulannya sesuai dengan pendapatan BMT yang telah mengelola uang nasabah tersebut. Dan dapat mengganti nisbah atau bagi hasil asal sesuai dengan kesepakatan bersama.

2. Simpanan Berjangka Barokah (SIBERKAH) Simpanan berjangka barokah ini menggunakan akad Mudharabah mutlaqah, dimana mudharib memberikan kepercayaan untuk memanfaatkan dana yang dapat di gunakan dalam bentuk pembiayaan secara produktif. Menurut bapak Dede Ratya selaku kepala cabang simpanan ini sangat membatu BMT karena sifat dari rekening yang hanya bisa diambil dalam jangka waktu 3, 6, 12 bulan dan dari jangka waktu itulah BMT dapat memaksimalkan dana untuk memperoleh keuntungan dari pengelolaan simpanan berjangka barokah. Dan bisa membagi hasil tersebut kepada nasabah. Adapun perhitungan bagi hasilnya yaitu saldo rata-rata simpanan berjangka barokah : jumlah akumulatif simpanan berjangka barokah $\mathrm{x}$ nisbah $\mathrm{x}$ porsi bagi hasil. Berikut adalah perhitungan yang sudah melakukan simpanan berjangka barokah yang menggunakan akad Mudharabah :

Simpanan berjangka barokah nasabah sebesar Rp. 1.000.000,- dengan jangka waktu 3 bulan. Dengan kesepakatan 50:50 (nasabah ingin membagi rata hasil tersebut walaupun pihak BMT sudah menawarkan 30:70 nasabah bilang itu tidak adil walaupun pihak BMT yang mengelola) dengan saldo pinjaman anggota sebesar Rp. 50.000.000,- dan 


\section{EKSISBANK Vol. 4 No. 1 Juni 2020}

pendapatan bagi hasil pembiayaan BMT sebesar Rp. 13.000.000,- berikut perhitungannya :

Rp. $1.000 .000,-\times$ Rp. $13.000 .000,-\times 50 \%=$ Rp. 130.000,-

Rp. 50.000.000,-

Maka jumlah bagi hasil yang diterima nasabah sebesar Rp. 130.000,- bagi hasil tersebut bisa saja berubah ketika pembagian bagi hasilnya dirubah tidak 50:50 .

Jika nasabah mengambil simpanan berjangka barokah sebelum jatuh tempo yang ditetapkan tidak dikenakan pinalti atau denda tetapi aturan ini mengubah ketentuan jika nasabah mengambil sebelum jatuh tempo maka nasabah dikenakan biaya sebesar Rp. 50.000,- untuk dibayarkan kepada BMT. Nasabah tidak akan mendapatkan bagi hasil karena nasabah tidak mengambil sesuai jangka waktu yang disimpan sesuai jangka waktu yang ditetapkan

Sedangkan untuk produk pembiayaan hanya satu yang menggunakan akad Mudharabah : Pembiayaan Mudharabah Pembiayaan Mudharabah ini menggunakan Mudharabah mutlaqah artinya pihak BMT memberikan kebebasan kepada nasabah untuk menjalankan ushanya, seperti jenis kegiatan usaha, tempat, waktu dan ketentuan lainnya. ketentuan pembiayaan menurut Fatwa DSN tentang pembiayaan Mudharabah: kriteria pengusaha, prosedur pembiayaan, dan mekanisme pembagian keuntungan. Berikut cara menentukan bagi hasilnya :

Nasabah mengajukan pembiayaan pada tanggal 10 oktober 2018 untuk menjalankan usaha dirumah dengan mengajukan sebesar Rp. 6.000.000 dengan jangka waktu 12 bulan dengan keuntungan bersih nasabah sebesar 1.500.000, rincian data diatas sebagai berikut: Jumlah modal yang diberikan kepada nasabah $=$ Rp. 6.000 .000

Dengan nisbah bagi hasil 30:70.

Modal Rp. 6.000.000 / 12 bulan = Rp. 500.000,-

Keuntungan Rp. 1.500 .000 x $30 \%=\mathrm{Rp}$. 450.000,-
Angsuran 1 bulan Rp. 500.000 + keuntungan yang sudah dibagi Rp. 450.000,- = Rp. 950.000,-

Dengan demikian angsuran yang harus dibayar satu bulan pada tanggal 12 november 2018 sebesar Rp. 950.000,- sudah ditambahkan dengan nisbah bagi hasilnya. Angsuran bisa saja berubah sesuai keuntungan yang didapat nasbah setiap bulan dan melaporkan setiap keuntungan perbulan. (jatuh tempo pembayaran pada tanggal 12).

BMT Al-Amanah cabang subang menggunakan metode dengan pembagian nisbah 30:70, pembagian tersebut bisa saja berubah jika salah satu pihak ingin mengganti pembagian nisabah tersebut, jadi keuntungan nisbah yang didapatkan oleh BMT tidak rata setiap bulan, karena setiap bulannya pasti ada perubahan keuntungan, entah itu presentase nya naik atau menurun. Dari ketiga produk yang saya bahas diatas menggunakan akad Mudharabah, margin atau bagi hasilnya yang berbeda, kenapa? karena dari beberapa produk tersebut ketentuan dan syarat-syarat yang dilakukan antara pihak BMT dan nasabah berbeda-beda. Tetapi dalam ketetapan syariah boleh saja dilakukan berbeda, karena pada dasarnya akad kerja sama Mudharabah tersebut yaitu kesepakatan kedua belah pihak, antara pihak BMT dan nasabah yang melakukan transaksi dengan akad Mudharabah tersebut. Dan boleh saja jika dari salah satu produk tersebut nasabah meminta agar margin atau bagi hasilnya diganti dengan kriteria nasabah harus menyerahkan kenaikan atau penurunannya pendapatan yang dikelola oleh nasabah. Agar pihak BMT mempertimbangkan mengganti margin tersebut dengan catatan harus sesuai kesepakatan bersama dan sesuai dengan syarat dan rukun akad Mudharabah. Dengan demkian sekali lagi, selama transaksi berpedoman dengan prinsip-prinsip syariah islam dan terpenuhinya rukun dan syarat yang ada, maka praktek Mudharabah menjadi sah, baik dalam akad maupun pelaksanaanya. 


\section{KESIMPULAN}

Kegiatan Simpanan dan Pembiayaan Mudharabah yang ada di BMT Al-Amanah Cabang Subang sudah sesuai syariah karena dari proses bagi hasilnya walaupun beragam atau tidak terpaku pada satu nisbah untuk semua produk yang menggunakan akad Mudharabah tetapi landasan syariah dilaksanakan dan disepakati oleh kedua belak pihak yang melakukan kerja sama.

Sistem transaksi yang digunakan di BMT AlAmanah cabang subang ini menggunakan Mudharabah mutlaqah dan Mudharabah muqayaddah dengan menggunakan prinsip revanue sharing dan profit sharing.

Dengan adanya BMT Al-Amanah Cabang Subang dapat menarik masyarakat untuk melakukan simpanan dan melakukan pembiayaan dengan produk andalan yang ada di tempat tersebut karena lebih membantu dalam menjaga keuangan dan mendapatkan keuntungan yang sesuai syariah serta dapat menarik masyarakat lain untuk melakukannya, selain itu para nasabah pun lebih terbantu dalam mengembangkan usahanya dengan adanya produk pembiayaan jenis Mudharabah ini, berikutnya dampak dari pembiayaan ini membantu mengurangi pengangguran.

\section{DAFTAR PUSTAKA}

Ahmad, D., Sucipto, M. C., \& Nurhayati, R. (2019). Analisis Penerapan Akad Mudharabah Pada Pemberian Modal Pakan Ikan Berdasarkan Kajian Ekonomi Syari'ah. Eksisbank, 3(2), 131-135.

Antonio, M. S. (2001). Bank Syariah Dari Teori Ke Praktik. Gema Insani Press.

Arianti, F. (2018). Mudharabah Dalam Bank Syariah. JURIS (Jurnal Ilmiah Syariah), 10(1).

https://doi.org/10.31958/JURIS.V10I1.922

Bagoes, I. M. (2004). Filsafat Penelitian \& Metode Penlitian Sosial. Pustaka Belajar.

Handayani, S. Z. H. (2013). Aplikasi Konsep Akad Murâbahah pada BPRS Metro Madani Cabang Kalirejo Lampung Tengah | Adzkiya: Jurnal Hukum dan Ekonomi Syariah. http://e-journal.metrouniv.ac.id/- index.php/adzkiya/article/view/1058

Hendri, S. (2013). Sistem Bagi Hasil Perkebunan Kelapa Sawit Ditinjau Menurut Perspektif Hukum Islam (Studi Kasus Di Desa Kota Garo Kecamatan Tapung Hilir Kabupaten Kampar). UIN Sultan Syarif Kasim Riau.

Janwari, Y. (2015). Fikih Lembaga Keuangan Syari'ah. Rosda Karya.

Malik, A. D. (2017). Analisa Faktor - Faktor Yang Mempengaruhi Minat Masyarakat Berinvestasi Di Pasar Modal Syariah Melalui Bursa Galeri Investasi Uisi. Jurnal Ekonomi Dan Bisnis Islam (Journal of Islamic Economics and Business), 3(1), 61. https://doi.org/10.20473/jebis.v3i1.4693

Mulato, T. (2019). Good Corporate Governance For Sharia Micro Financial Institution. IECONOMICS: A Research Journal on Islamic Economics, 4(2), 159-179. https://doi.org/10.19109/ieconomics.v4i2.25 18

Satya, D. (2019). Produk Akad Mudharabah.

Sofiana, T. (2014). Konstruksi Norma Hukum Koperasi Syariah Dalam Kerangka Sistem Hukum Koperasi Nasional. JURNAL HUKUM ISLAM, I(1). https://doi.org/10.28918/jhi.v1i1.535

Sumirto, W. (2002). Asas-asas Perbankan Islam dan Lembaga-Lembaga Terkait BMI. Raja Grafindo Persada.

Yarmunida, M., \& Wulandari, W. (2018). Penetapan Nisbah Bagi Hasil Pada Akad Kerjasama Pemeliharaan Hewan Ternak Perspektif Ekonomi Syariah. Jurnal BAABU AL-ILMI: Ekonomi Dan Perbankan Syariah, 1(1). https://doi.org/10.29300/BA.V1I1.851

Yuliadi, I. (2001). Ekonomi Islam Sebuah Pengantar. LPPI.

Rina Lestari | Pelaksanaan Bagi Hasil Simpanan ...... | 38 